\title{
Educational Leadership Is Not About Money
}

Thomas F. Kelly, Ph. D. Dowling College, USA

\begin{abstract}
This paper presents a systems approach based on the work of W. Edwards Deming, an alternative to the all purpose "We need more money" solution.
\end{abstract}

Keywords: Systems; do more with less; Deming

\section{INTRODUCTION}

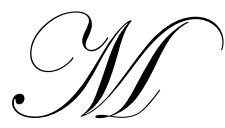

oney is not the Problem. It never was the Problem and it's not the Problem Now

Restructure public school systems and other organizations to increase productivity while reducing required resources. Systems thinking can solve not only our educational improvement and funding problems but most of our economic problems.

For at least several decades the annual increases in the cost of public education have risen considerably faster than the increases in taxpayers' incomes. Even before the current fiscal crisis these two rising lines of contingency have been approaching a point at which they cross and public education will price itself out of existence. Its demise will not be because people don't want public education but because they simply can't afford it.

The present crisis, which seems destined to get worse and last for a long period of time, has drastically compounded this problem. America must reconsider how we use tax revenues and how we can do better while spending less on education and all other public services. Two examples of systemic change that have increased productivity while decreasing necessary resources come to mind.

\section{SUCCESSFUL EXAMPLES OF SYSTEMIC CHANGE}

The bridges and tunnels across the Hudson River created extensive traffic delays between New York City and New Jersey for over 50 years. Then efforts began to change the structure of the system. First exact change lanes were created. This increased productivity (improved traffic flow) while reducing required resources (toll takers). Next they decided to double the tolls and collect them one way. This significantly increased productivity and further reduced required resources. Then they created EZpass which further increased productivity and reduced required resources. resources.

Most recently they created express EZpass which further increased productivity while reducing required

Additional benefits include reduced travel time, reduced gas consumption, reduced air pollution, and reduced motorist stress from driving. All improvements were accomplished while using fewer resources.

It is interesting to note that Departments of Transportation around the country are generalizing the New York State experience and implementing the above structural changes not only for river crossings but also for toll collection on highways and interstates all across the nation. The decreases in necessary resources, traffic delays, gas consumption, travel time, and motorist stress, etc. nationally are incalculable. 
A second example of systemic change that has increased productivity while decreasing necessary resources is the change in the New York State Department of Motor Vehicles (DMV). For decades the DMV was notorious for its long lines and inconvenience. A trip to the DMV was generally viewed like a trip to the dentist. Then it made structural changes.

Instead of annual renewal of licenses and registrations DMV instituted multiyear renewals for both. These changes dramatically increased productivity while reducing required resources. Next they made renewal of drivers' licenses and registrations via the mail and then registrations via email. All DMV forms are now available on the web.

Each of these structural changes increased productivity while decreasing required resources. Citizens received far better service, more rapidly and with less time and travel as well.

\section{OTHER POSSIBLE SYSTEMIC IMPROVEMENTS}

Three additional examples of possible systems solutions to improving productivity while decreasing resources/costs are cited below.

1 The post office is currently running multibillion dollar deficits. They suggest reducing mail delivery from six days to five as a means to cut costs though this will still require increases in costs. Their solution is to increase costs while reducing service.

If we restructure the post office we can reduce mail delivery to three days a week and get it every other day. This will enable each mail carrier to deliver the mail on two routes thus cutting the number of carriers needed by half. Keep special delivery for those who must receive their bills every day. (Electronic billing is making this a moot point.)

In addition technology can be used to allow citizens to opt out of delivery of junk mail.

This will significantly reduce the cost of the postal service. The unending increases will cease. It will improve service while reducing amounts of mail to be delivered. Unnecessary postal workers can be retrained and/or redeployed to productive work.

2 Prison overcrowding is used to justify early release of dangerous felons. e. g. February 2009 a California court ordered the possible release of 45,000 inmates due to overcrowding. New and existing prisons are very expensive to build, staff and maintain.

Once again restructuring use of existing resources offers a much better solution. All across America we have vacant military bases generally surrounded by depressed communities they used to employ. During World War 2 vacant military bases were used to house prisoners of war. Since these facilities were and are adequate for training American citizen soldiers they will be adequate for convicted felons. These prisons could hold the nonviolent and less serious criminals.

This will create jobs for those communities that want such facilities in their areas. It will reduce crime due to felons serving their full terms. It will reduce violence to innocent people and destruction of property. While some modifications will be necessary as was the case during WW2, use of these existing vacant resources will cost far less than new prison construction and eliminate the need for new physical resources. It will also be much cheaper to staff and maintain these facilities and save substantial taxes.

3 Nationally there is presently a high percentage of uninsured drivers. Exact numbers nationally are unknown but are obviously very large. The costs for their insurance are being born by those who play by the rules. 
Reorganizing resources again offers a way to improve/solve the problem (improve productivity) while reducing costs to those who play by the rules. We can establish a national no fault insurance system. By adding a tax to gas at the pump we can reduce the number of uninsured motorists to zero. Currently uninsured motorists will not only be insured but pay for it themselves.

This reorganization has additional benefits. It creates incentive to buy fuel efficient cars and will reduce air pollution and carbon dioxide. It also creates a labor pool of former insurance for retraining and of redeployment to productive work. (We did not think of this example ourselves but don't know who did.)

The above are some presently existing and possible future examples of using systems thinking to improve productivity while decreasing necessary resources. Every organization, private as well as public, should look at itself in systems terms to find ways to do the same. The potential for improving economic and other forms of productivity while reducing resources is limitless.

Those who become unemployed in this process represent a valuable labor pool that can be retrained if necessary and redeployed in productive work. It is a legitimate function of government to provide the means for ongoing education and retraining for all those who will need it. The best investment the United States Government ever made is the G I Bill. It led to millions of Americans going to college and tens of millions of their children going to college and graduate school. Income thus earned has generated an exponential return (taxes paid to the treasury) on the investment (taxes used) to fund it. This includes both the increase in the income of our citizenry but also the higher tax revenues generated for government.

\section{SYSTEMIC CHANGE OF PUBLIC EDUCATION}

We frequently hear calls for consolidation of school systems as a means of saving money. While this might save some money there is a way to restructure that will save much more. Instead of centralizing which builds and or expands bureaucracy go the other way - decentralize all school systems to the building level.

Each school would get its funds in a block. The principal can run the school answerable to a small board of local citizens as is already done in thousands of private schools.

Schools can contract out for services such as transportation, payroll processing and any other the school cannot perform efficiently, as is now done by private schools and companies all across the country.

This simple governance structure does not hurt private schools which consistently outperform the public. It would certainly result in no less achievement and probably more in public schools.

Probable results of restructuring public schools to the building level include:

1. Save many teacher jobs in the present economic climate. The biggest item by far in any education budget is personnel. In the coming years we face the loss of a great many teachers.

2. Very big annual savings - we probably spend from 10 to 30 percent of education budgets on central administration depending on the size of the system.

3. Greater accountability - the smaller the organization, the greater its transparency.

4. Place authority for results in the local board and Principal (who is now accountable but does not have proportionate authority for decisions in the school).

5. Probably much better student achievement results. The present bureaucratic structure has most decisions affecting students made by people who are distant from them.

6. Cut bureaucracy and red tape. Bureaucracies tend to become their own reason to exist. Their primary goal becomes preservation and extension of the bureaucracy. Those closest to the job tend to know best what is needed to improve production. In the case of education schools are closest to the children and most aware of student needs. 
7. Far less opportunity for misuse and theft of funds. The larger the organization the greater the chances of distant bureaucrats making decisions about resource allocations that are less positive in their impact on students.

8. The need for any centralized services could be contracted out as businesses do, instead of duplicating them in each school district.

9. Probably lots of other benefits if we think about it.

This transition should be voluntary. Voters in each school district could decide if they want it.

\section{USE TECHNOLOGY TO IMPROVE STUDENT ACHIEVEMENT WHILE CUTTING COSTS}

The power of technology to engage and hold student attention when properly used is well known. With the right software, equipment and training we can increase class size while improving student achievement.

Of course many of the vested interests will resist. To the extent possible central office staff can be offered positions in the schools.

In the present economic climate we are facing massive teacher layoffs, probably for many years to come. Teachers unions probably will resist increasing class size through use of technology but would endorse restructuring through decentralization to save teaching positions. Most principals and teachers would also prefer decision making closer to the school than is generally the present case.

Tax payers would support it based on the probability of significant annual savings and greater student achievement.

This educational restructuring would save NYS alone many billions annually. On a national level it would save hundreds of billions annually.

This proposal for school improvement looks at the governance structure of schools for improvement. There are many other "subsystems" in education besides governance that can also be restructured.

The two examples of bridges and tunnels and the DMV made extensive use of technology in their restructuring processes. The schools can do the same to further significantly increase productivity and reduce resources. A topic for much greater future discussion.

\section{AUTHOR INFORMATION}

Thomas Kelly, Ph. D. is Associate Professor of Educational Administration, Leadership and Technology at Dowling College in Oakdale, NY

\section{BIBLIOGRAPHY}

1. Deming, W. Edwards. The New Economics for Industry, Government and Education. Cambridge Massachusetts, MIT Press, 2002.

2. Deming, W. Edwards. Out of the crisis. Massachusetts: Institute of Technology Center for Advanced Engineering Study, 1986.

3. Kelly, T. (2007). Bridges, Tunnels and School Reform: It's The System Stupid. Phi Delta Kappan, 89, 151- 152. This article is one of three chosen by Kappan for audio downloading available to PDK members from their web site as an MP3 file.

4. Kelly, Thomas. Bridges and tunnels and school reform: It's the system stupid. Manuscript in progress, 2009.

5. Kelly, Thomas. Practical strategies for school improvement. Wheeling, Illinois: National School Services, 1992. (Also available in Spanish.) http://www.n-s-s.com/school_improvement/practical_strategies.html 